\title{
FORUM
}

Submitted 06.29.2016. Approved 02.08.2017

Evaluated by double blind review process. Scientific Editors: Adriana Roseli Wünsch Takahashi, Sergio Bulgacov, Claudia Cristina Bitencourt and Hale Kaynak

http://dx.doi.org/10.1590/So034-759020170303

\section{IT-ENABLED DYNAMIC CAPABILITY ON PERFORMANCE: AN EMPIRICAL STUDY OF BSC MODEL}

\author{
Capacidade dinâmica de Tl e desempenho: Um estudo empírico do modelo BSC \\ Capacidad dinámica de TI y desempeño: Estudio empírico del modelo BSC
}

\begin{abstract}
Few studies have investigated the influence of "information capital," through IT-enabled dynamic capability, on corporate performance, particularly in economic turbulence. Our study investigates the causal relationship between performance perspectives of the balanced scorecard using partial least squares path modeling. Using data on 845 Brazilian companies, we conduct a quantitative empirical study of firms during an economic crisis and observe the following interesting results. Operational and analytical IT-enabled dynamic capability had positive effects on business process improvement and corporate performance. Results pertaining to mediation (endogenous variables) and moderation (control variables) clarify IT's role in and benefits for corporate performance.
\end{abstract}

KEYWORDS | Corporate performance, information technology, dynamic capability, business process improvement, economic turbulence.

\section{RESUMO}

Poucos estudos já investigaram a influência do "capital de informação", através da capacidade dinâmica de TI, sobre o desempenho corporativo, particularmente em uma turbulência econômica. Nosso estudo investiga a relação causal entre perspectivas de desempenho do balanced scorecard, utilizando modelagem de caminho pelos mínimos quadrados parciais. Utilizando dados sobre 845 empresas brasileiras, desenvolvemos um estudo empírico quantitativo com empresas durante uma crise econômica, e observamos os seguintes resultados de interesse: a capacidade dinâmica de TI operacional e analítica teve efeitos positivos na melhoria dos processos de negócios e no desempenho corporativo; os resultados relacionados à mediação (variáveis endógenas) e à moderação (variáveis de controle) esclarecem o papel da TI e seus benefícios para o desempenho corporativo.

PALAVRAS-CHAVE I Desempenho corporativo, tecnologia da informação, capacidade dinâmica, melhoria de processos de negócios, turbulência econômica.

\section{ADILSON CARLOS YOSHIKUNI ayoshikuni@fgvmail.br Professor da Fundação Getulio Vargas, Escola de Administração de Empresas de São Paulo - São Paulo - SP, Brazil}

\section{ALBERTO LUIZ ALBERTIN albertin@fgv.br Professor da Fundação Getulio Vargas, Escola de Administração de Empresas de São Paulo - São Paulo - SP, Brazil}

\section{RESUMEN}

Pocos estudios han investigado la influencia del "capital de la información", a través de la capacidad dinámica posibilitada por TI, sobre desempeño corporativo, especialmente en turbulencia económica. Nuestro estudio investiga la relación causal entre perspectivas de desempeño del balanced scorecard usando el modelado path de mínimos cuadrados. Utilizando datos sobre 845 empresas brasileñas, conducimos un estudio empírico cuantitativo de firmas durante una crisis económica y observamos los siguientes resultados interesantes. La capacidad operativa y analítica posibilitada por TI tuvo efectos positivos en la mejora de procesos empresariales y desempeño corporativo. Los resultados referentes a mediación (variables endógenas) y moderación (variables de control) aclaran el papel de $\mathrm{Tl}$ y beneficios en el desempeño corporativo.

PALABRAS CLAVE / Desempeño corporativo, tecnología de la información, capacidad dinámica, mejora de procesos empresariales, turbulencia económica. 


\section{INTRODUCTION}

The resource-based view (RBV) and information technology (IT) business alignment approaches dominate IT literature (Schwarz, Kalika, Kefi, \& Schwarz, 2010). RBV theory (Barney, 1991) has a static aspect, characterized by inability to obtain resources to enable sustainable competitive advantage (Barney \& Clark, 2007).

Dynamic capability (DC) arises from the RBV on environmental prospects that have a high change rate, enables complementary resources (Ambrosini \& Bowman, 2009; Helfat et al., 2009; Wade \& Hulland, 2004), and reconfigures resources to meet requirements and changes in external and internal environments (Teece, 2009, 2014; Teece, Pisano, \& Shuen, 1997).

Since 2015, Brazilian companies have faced political and economic crises. Economic turbulence was negative (-3.8\%) in 2015 (Instituto Brasileiro de Geografia e Estatística [IBGE], 2016), and the forecast for 2016 shows no change. In 2015, 580,000 companies ceased activity (IBGE, 2016) and listed companies' revenues fell by $5.4 \%$ from 2014 to 2015 according to the Economatica System.

In 2015 , IT spending increased to $7.6 \%$ of Brazilian companies' revenues (GVCia, 2015). Per Albertin and Albertin (2016), during the economic crisis, IT investments were made to achieve efficiency and efficacy and promote productivity.

Per Augier and Teece (2009), managers must build dynamic capabilities to sense and seize opportunities, transforming and reconfiguring as opportunities and competitive forces dictate. Raschke (2010) suggests that IT-enabled dynamic capability (ITDC) allows organizations to design and reconfigure processes to improve efficiency, enabling new business forms (Anderson, Banker, \& Ravindran, 2006), and to influence corporate performance (Brynjolfsson \& Hitt, 1996; Stoel \& Muhanna, 2009) and react to changing business conditions and corporate strategies under economic pressure (Kim, Shin, Kim, \& Lee, 2011; Weill, Subramani, \& Broadbent, 2002).

Since the 1990s, most corporate performance studies have increased used the balanced scorecard (BSC) of Kaplan and Norton (1992). As of May 2016, their paper, "The balanced scorecard: Measures that drive performance” (Kaplan \& Norton, 1992), has been cited more than 1,945 times, per the Web of Science's Scholarly and Scientific Research. Some studies (Bento, Bento, \& White, 2013) estimate that $60-70 \%$ of large organizations in the private, public, and nonprofit sectors have adopted the BSC. Kaplan (2010) highlights future opportunities to statistically investigate causal relationships among BSC perspectives and objectives, helping firms understand and use dynamic causal models effectively to guide strategies and operations.

This study investigates the relationship between ITDC, business process improvement (BPI), customer performance
(CP), and financial performance (FP), using the BSC model to help managers understand ITDC's role in corporate performance during economic turbulence. We validate analytical and operational ITDC as a first-order construct, analyzing the mediation of all endogenous variables and checking the influences of control variables (sector and firm size) on the relationships between all latent variables. Figure 1 depicts our ITDC model of corporate performance measured using the BSC method.

Figure 1. Proposed ITDC model of corporate performance

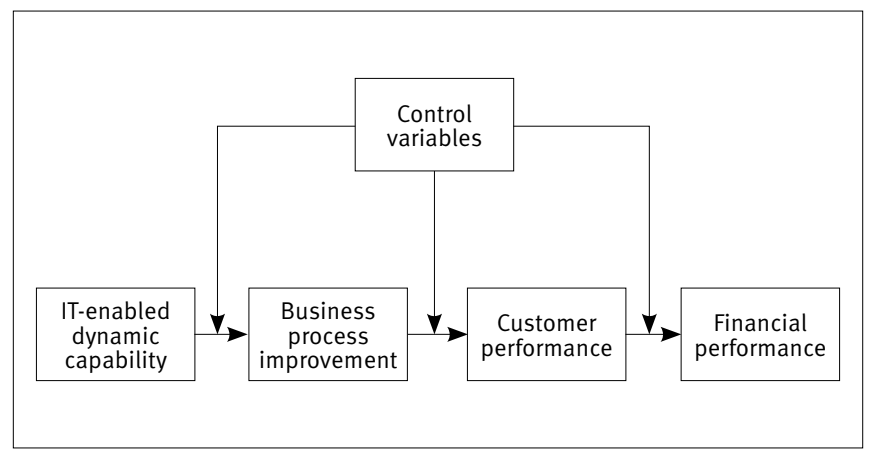

\section{THEORY AND HYPOTHESIS DEVELOPMENT}

This section describes dynamic capability, IT-enabled dynamic capability, operational IT, analytical IT, and the BSC model.

\section{Dynamic capability}

DC originates in RBV theory (Wang \& Ahmed, 2007), encouraging efficient resource management to improve business processes (Grant, 2010) by choosing an activity set with a unique value combination (Kaplan \& Norton, 2000). Per the RBV, sustained competitive advantage comes from unique, distinguishing resources that may be valuable, rare, non-replicable, and non-substitutable (Birkinshaw \& Goddard, 2009; Wade \& Hulland, 2004).

The heterogeneity and immobility of certain resources make it difficult to obtain DC in volatile environments and conditions (Wade \& Hulland, 2004).

Several studies have highlighted firm-level DC development relating to challenging external and internal environments (Augier \& Teece, 2009; Eisenhardt \& Martin, 2000; Helfat \& Peteraf, 2009; Helfat \& Winter, 2011; Teece et al., 1997). This capability includes the ability to react dynamically through internal activities (Eisenhardt \& Martin, 2000; Teece, 2009; Winter, 2003; Zollo \& Winter, 2002) and through other means (McKelvie \& Davidsson, 2009; Pavlou \& Sawy, 2011; Ravichandran \& Lertwongsatien, 
2005; Wang \& Ahmed, 2007; Zahra, Sapienza, \& Davidson, 2006), allowing an organization to reconfigure resources and organizational capability (Ambrosini \& Bowman, 2009; Helfat \& Peteraf, 2009; Meirelles \& Camargo, 2014; Teece, 2014).

We define DC as a firm's ability to develop or maintain competitive advantage using its essential competence and collective ability to innovate, coordinate, and reconfigure internal resource skills. Thereby, the firm improves business processes, meets market challenges, and influences corporate performance under economic turbulence.

\section{IT-enabled dynamic capability}

Most IT research defines IT resources and their relationship with competitive advantage, business strategy, and corporate performance (Davenport \& Harris, 2007; Davenport, Harris, \& Morison, 2010; Helfat \& Winter, 2011; Kim et al., 2011; Wade \& Hulland, 2004). Bharadwaj (2000) claims that IT enables DC, promoting BPI. IT integrates, builds, and reconfigures internal competencies in value chain activities (Davern \& Wilkin, 2010; Kim et al., 2011; Raschke, 2010). Its benefits lead to competitive advantage (Bhatt \& Grover, 2005; Schwarz et al., 2010; Stoel \& Muhanna, 2009).

IT use leads to operational (Bhatt \& Grover, 2005; Melville, Kraemer, \& Gurbaxani, 2004; Schwarz et al., 2010) and analytical benefits (Arnott \& Pervan, 2014; Davenport \& Harris, 2007; Davenport et al., 2010; Nudurupati, Bititci, Kumar, \& Chan, 2011; Ramdani, 2012; Wade \& Hulland, 2004), and influences BPI and corporate performance (Kohli, Devaraj, \& Ow, 2012; Melville, Kraemer, \& Gurbaxani, 2004; Nudurupati, Bititci, Kumar, \& Chan, 2011).

We define ITDC as a firm's ability to change (improve, adapt, or reconfigure) a business process better than competitors by integrating activities, reducing cost, and capitalizing on business intelligence/learning (Schwarz et al., 2010).

\section{Operational IT}

Operational IT is categorized into technological infrastructure and transactional applications (Chuang, 2004; Maçada, Beltrame, Dolci, \& Becker, 2012; Sobol \& Klein, 2009) and automates activities (Otim, Dow, Grover, \& Wong, 2012; Shang \& Seddon, 2002).

Technological infrastructure enables connections between companies, information sharing, and data structuring, and deploys IT business value across an enterprise (Bhatt \& Grover, 2005; Weill et al., 2002). Communication enabled by IT infrastructure among functions generates DC, which provides integration, flexibility, standardization, and business agility, and reduces IT cost.
IT transactional applications automate operational tasks and generate information, which ellucidates the activities through which a firm makes and delivers business value (O'Brien \& Marakas, 2007; Ravichandran \& Lertwongsatien, 2005; Shang \& Seddon, 2002). DC enabled by IT business value uses technology to process and automate basic repetitive transactions and create information availability for business management (Raschke, 2010). IT in material requirement planning (MRP) designs, monitors, and controls floor shop routines, generating agility, flexibility, simulation power, and control, thereby recommending "what, when, and how" for production and "what, when, and where" for supplies and raw materials purchasing.

\section{Analytical IT}

Analytical IT enables tactical and strategic decision-making. Per Davenport and Harris (2007) and Davenport et al. (2010), management uses IT to provide analyses, data, and systemic knowledge for organizational processes and decision-making.

Tactical IT capability improves information quality, defined by accessibility, accuracy, and flexibility (Chuang, 2004; Maçada et al., 2012; Sobol \& Klein, 2009). IT provides and uses information for the planning, execution, and control of activities (Arnott \& Pervan, 2005, 2014; Singh, Watson, \& Watson, 2002). IT provides information to run a firm and achieve objectives and targets (Arnott \& Pervan, 2014), enabling analysis and measurement of time variations, and redirecting actions that contribute to operational productivity (Kaplan \& Norton, 2008).

Strategic IT capability contributes to competitive advantage development (Melville et al., 2004) and helps increase market share. Strategic IT applications relate to a firm's core business, enabling a firm to competitively differentiate by aligning to customer needs (Ramdani, 2012).

Organizations react to external environments and create performance management models to understand and adapt (Kaplan \& Norton, 1996). The relationship between external factor stimuli and strategy development is relevant to acquisition and creates IT capabilities (Kaplan \& Norton, 2000). The performance management model of BSC proposed by Kaplan and Norton (1996, 2000, 2004, 2008) shows that IT enables organizations to respond to external and internal challenges through operational business processes, such as innovation, operation, and post-sale. Melville et al. (2004) find that IT business value is created when organizations understand how to develop IT to support business processes and achieve corporate performance that responds to environmental challenges. IT can be explained by how effectively a firm uses information systems (IS) to support and enhance core competencies (O’Brien \& Marakas, 2007; Ravichandran \& 
Lertwongsatien, 2005; Sen, Bingol, \& Vayvay, 2017) to enable operational dynamic capability in the BSC model.

$\mathrm{H}_{1}$ : Operational IT-enabled dynamic capability is positively associated with business process improvement.

External factors' impact on competitive advantage and firm performance depends on how firms develop dynamic capabilities for using management resources (Augier \& Teece, 2009). Through information systems, IT enables managers to use performance management models (O’Brien \& Marakas, 2007) such as the BSC systems to develop dynamic capabilities for responding to external changes (Sen et al., 2017). Per Kaplan and Norton (2000, 2008), strategic maps, dashboards, cockpits, and performance reports provide information to develop knowledge and provide intelligence to managers for decision-making. Organizational IT resources transform and create ways to run business processes (Henderson \& Venkatraman, 1999) by developing new products and services or making efficiency gains (Maçada et al., 2012). IT is used in strategic processes to generate DC, which diagnoses, plans, formulates, and implements business strategies with flexibility, thus adapting, transforming, and achieving business process improvement in the BSC model (Arnott \& Pervan, 2014; Ramakrishnan, Jones, \& Sidorova, 2012).

H2: Analytical IT-enabled dynamic capability is positively associated with business process improvement.

We describe ITDC's principal contributions (Schwarz et al., 2010) and BSC (Kaplan \& Norton, 1996), presenting IT as a resource that enables dynamic capabilities in business process improvement to achieve performance. We focus on the influence of "information capital provided by the BSC" because analytical and operational ITDC runs across all activities in the value chain. We concentrate on technology benefits offered and delivered by IT (Henderson \& Venkatraman, 1999; Kohli \& Grover, 2008; Otim et al., 2012; Poelmans, Reijers, \& Recker, 2013; Tallon, 2008) to enable DC to achieve BPI (Helfat \& Winter, 2011; Kim et al., 2011; Melville et al., 2004; Raschke, 2010; Schwarz et al., 2010); to respond to market challenges and develop internal competencies to innovate, coordinate, and reconfigure processes (Ambrosini \& Bowman, 2009; Teece et al., 1997); and to influence multiple corporate performance perspectives (Devaraj \& Kohli, 2000, 2003; Henderson, Kobelsky, Richardson, \& Smith, 2010; Kohli, Devaraj, \& Ow, 2012; Santos, Zheng, Mookerjee, \& Chen, 2012; Teece, 2009).

\section{Balanced scorecard model}

The BSC is an integrated framework to track financial and nonfinancial indicators, helping an organization align its initiatives with strategy and achieve corporate performance (Bento et al., 2013; Brito \& Brito, 2012; Kaplan, 2010; Sen et al., 2017; Yoshikuni \& Albertin, 2014). Corporate performance is measured from the multidimensional prism perspective (Najmi, Etebari, \& Emami, 2012), through financial and nonfinancial measures (Ouakouak \& Ouedraogo, 2013; Santos-Vijande, LópezSánchez, \& Trespalacios, 2012) of causal relations, within and between strategy objectives that culminate in FP.

Senior managers have focused on understanding how FP is created by identifying, measuring, and managing longterm shareholder value drivers (Brito \& Brito, 2012; Bryant, Jones, \& Widener, 2004; Jordão \& Novas, 2013; Sen et al., 2017). Increased profitability results from revenue growth and spending reduction (cost, expenses, and asset use) (Atkinson, Kaplan, Matsumura, \& Young, 2011). Revenue growth is necessary to satisfy clients; managerial actions and decisions can increase productivity. Profits could increase indirectly through production, increasing market share and generating higher revenues and lower operational spending (Kaplan \& Norton, 2008; Papke-Shields, Malhotra, \& Grover, 2006). To achieve $\mathrm{BPI}$, an organization must develop intangible asset capability in information capital, human capital, and organization capital (Kaplan \& Norton, 2004).

The BSC model describes causal relationships between performance measures by considering strategic business goals from four perspectives: financial, customer, business processes, and learning and growth. We draw on Kaplan and Norton (2008) to describe the BSC model's perspectives.

FP includes the primary objective of sustained shareholder value creation and sub-objectives of revenue growth, productivity, and risk management (Kaplan, 2010). FP relates to the ability to create long-term value for shareholders (Atkinson et al., 2011; Kaplan \& Norton, 2008; Kohli et al., 2012; Ouakouak \& Ouedraogo, 2013; Santos-Vijande et al., 2012; Yoshikuni \& Albertin, 2014).

The conditions that create value for clients impact CP (Kaplan \& Norton, 1996; Santos-Vijande et al., 2012). CP is measured by objectives relating to (a) attributes of goods and services, such as price, quality, time, availability, functionality, claims rate, and delivery reliability; (b) relationships with indicators, such as customer retention and partner satisfaction; and (c) image or brand (Kaplan \& Norton, 2008; Sila \& Ebrahimpour, 2005). CP is the organization's ability to fulfill attributes requested by clients, execute the business value chain's internal activities (Kaplan \& Norton, 2008), and create customer satisfaction, loyalty, and retention (Kaplan, 2010).

Per Melville et al. (2004), a business process is the ordering of work activities across time and space, with a beginning, 
end, and identified inputs and outputs. A business process comprises the value chain's internal activities, leading to financial productivity, success, and satisfied customers (Jordão \& Novas, 2013; Sen et al., 2017). The generic view of the internal business process perspective encompasses the entire internal value chain, decomposed into three processes: innovation, operations, and post-sales (Kaplan \& Norton, 2008). Innovation activities focus on identified markets and customer needs; products and services meet those needs. Kaplan and Norton (2008) conclude with post-sales services for operational activities in which the value proposed (products and services) is crafted and delivered to meet customer needs; if needs are unmet, corrective actions are applied to satisfy customers.

Achieving BPI requires learning and growth to develop the organization; employee capabilities and skills, constituting intangible assets; information systems capabilities (IT); and an enabling corporate climate (Kaplan \& Norton, 1996). An organization must provide employees with opportunities for growth and learning, creating a good work place (Jordão \& Novas, 2013). We concentrate "information capital” on ITDC.

$\mathrm{H}_{3}$ : Business process improvement is positively associated with customer performance.

$\mathrm{H}_{4}$ : Business process improvement is positively associated with financial performance.

$\mathrm{H}_{5}$ : Customer performance is positively associated with financial performance.

\section{RESEARCH METHODOLOGY}

In this section, sample, pilot test, data treatment, and statistical techniques are described.

\section{Sample}

The target population comprised organizations from several sectors, following Ouakouak and Ouedraogo (2013). We used research methods for business (Sekaran, 2000) and the recommendation of Tallon, Kraemer, and Gurbaxani (2000) to measure IT business value through executives' perceptions. This method has been used in IT studies (e.g., Kim et al., 2011; Papke-Shields et al., 2006; Powell \& Dent-Micallef, 1997), and the key informants were professionals with decision-making ability, including chief executive officers, vice presidents, directors, managers, supervisors, coordinators, and business executives involved in management.

We designed a firm-level sample, and respondents were employed professionals taking classes to fulfill Master of Business Administration (MBA) degrees (D’Arcy \& Devaraj, 2012) at a university in southwestern Brazil. The high-quality sample consisted of executives with eight to 30 years of experience in executive management.

To evaluate organizations' aspects accurately, we provided informants a 20-day period to validate survey information with other executives. During this period, respondents could call, email, or consult with us regarding the questionnaire, thereby increasing answer quality. Incomplete questionnaires were invalidated.

The questionnaire contained two sections: demographic and specific information. The demographic section sought data characterizing the firm and validating participation, including a direct search for secondary data. The specific information section assessed perception of the research constructs. Demographic information included control variables of sector and firm size (number of employees), incorporated as a moderating variable. The questionnaire's interval scale contained five choice categories for each manifest variable, evaluated along a Likert scale: (1) strongly disagree, (2) disagree, (3) neither agree nor disagree, (4) agree, and (5) strongly agree.

\section{Pilot test}

Manifest variables were obtained from the literature, as was guidance concerning variables' content validity, number of categories for items, and other issues (Hair, Black, Babin, Andersen, \& Tatham, 2009; Sekaran, 2000).

Experts (researchers and professors with more than 12 years of experience) in business strategy and technology pretested the questionnaire. The results were positive and confirmed the questionnaire's quality. The questionnaire was applied to a sample of 40 organizations, fulfilling the minimum pretesting recommendation of 15 respondents (Malhotra, 2006). Respondents rated format, ease of understanding content, and other aspects, most of which were acceptable. We incorporated evaluators' suggestions.

\section{Data treatment}

The data treatment phase included a check for missing values. Microsoft Excel 2010 stored records of 845 valid cases; 247 questionnaires had missing data and were excluded from the research database. 
We tested for nonresponse bias, comparing assessments of the pilot test respondents (early) and MBA respondents (late) for all variables. All $t$-test comparisons between the means of early and late respondents showed no significant differences (D'Arcy \& Devaraj, 2012). We tested the model with a dummy variable indicating whether a respondent was a pilot test case (40 cases) or MBA. The path from the dummy variable to firm performance was not significant (CP $\beta=0.022$, n.s. and financial performance $\beta=0.001$, n.s.) (Nitzl \& Hirsch, 2013).

The sample size accorded with partial least squares path modeling (PLS-PM) literature (Henseler, Ringle, \& Sinkovics, 2009; Sosik, Kahai, \& Piovoso, 2009; Urbach \& Ahlemann, 2010), which considers the minimum sample size to be 10 times the number of structural paths arriving at a particular reflective construct. The minimum sample size was 20 . For a more rigorous minimum sample size, we evaluated statistical power using the $G{ }^{*}$ Power 3.1.9.2 software (Faul, Erdfelder, Lang, \& Buchner, 2007). We observed two parameters: test power (power $=1-\beta_{\text {error prob. II) }}$ and the effect size $\left(f^{2}\right)$. Cohen (1988) and Hair, Hult, Ringle, and Sarstedt (2013) recommend a power of 0.80 and median $f^{2}$ of 0.15 They note that CP and FP constructs should have two predictors.

The minimum sample size suggested by the software was 43 , but to increase model consistency, doubling or tripling this value is beneficial (Ringle, Silva, \& Bido, 2014). We used a sample of 845 , complying with the empirical rule.

\section{Statistical technique}

PLS-PM calculates the maximum explained variance of all manifest variables, evaluates the reliability and validity of latent constructs, and estimates relationships between them (Hair et al., 2013). PLS-PM addresses situations observed in IT research (Ringle, Sarstedt, \& Straub, 2012): the absence of symmetric variable distributions (or those with little "consolidation") measured by a still-nascent theory, large data amounts, or limited data amounts. PLS-PM can demonstrate the model's applicability and robustness (Ringle et al., 2014).

The PLS-PM technique does not adhere to the normal distribution of data, a set number of data observations and independence, or metric uniformity of the variable (Chin, 1998; Hair et al., 2013). Despite this, we proceeded with caution and followed the recommendations of Chin (1998) and Hair et al. (2013) while preparing missing values and checking data distribution and multicollinearity. We used the SmartPLS 2.0 M3 program for PLS-PM (Ringle, Wende, \& Will, 2005).

The sample was defined by sector and firm size (number of employees), following Ray, Wu, and Konana (2009). Table 1 summarizes the sample profile and respondents.
Table 1. Demographic research

\begin{tabular}{l|c|c|c}
\hline \multicolumn{2}{c|}{ Sector } & \multicolumn{2}{c}{ Firm size } \\
\hline Type & $\%$ & (Numbers of employees) & $\%$ \\
\hline Agribusiness & 4 & Up to 250 & 32 \\
\hline Finance & 10 & 251 to 500 & 15 \\
\hline Manufacturing & 38 & 501 to 3000 & 12 \\
\hline Services & 40 & 3001 and more & 41 \\
\hline
\end{tabular}

\section{Measurement model}

We observe convergent validities by measuring the model's average variance extracted (AVE). Per the Fornell-Larcker criterion (Henseler et al., 2009), AVE should exceed 0.50 (Hair et al., 2013; Ringle et al., 2014). Table 2 presents results.

Composite reliability (CR) is the most appropriate measure for PLS-PM because it prioritizes variables by reliability (Ringle et al., 2014). We considered CR values between 0.70 and 0.90 satisfactory (Hair et al., 2013). Table 2 shows that $C R$ values are adequate. We evaluated the variables' normality by coefficients of skewness (Sk) and kurtosis (Ku), and univariate and multivariate variables showed no severe violation of the normal distribution assumption $(|S k|<3$ and $|K u|<10)$ (Marôco, 2010).

\section{Table 2. Pearson correlation and descriptive statistics of} latent variables

\begin{tabular}{|c|c|c|c|c|c|}
\hline Latent variables & 1 & 2 & 3 & 4 & 5 \\
\hline 1 - Operational ITDC & 0.79 & & & & \\
\hline 2 - Analytical ITDC & 0.78 & 0.80 & & & \\
\hline $\begin{array}{l}3 \text { - Business process } \\
\text { improvement }\end{array}$ & 0.50 & 0.51 & 0.73 & & \\
\hline 4 - Customer performance & 0.31 & 0.32 & 0.62 & 0.74 & \\
\hline 5 - Financial performance & 0.34 & 0.37 & 0.48 & 0.49 & 0.85 \\
\hline AVE & 0.62 & 0.65 & 0.53 & 0.55 & 0.72 \\
\hline Composite reliability & 0.87 & 0.88 & 0.77 & 0.78 & 0.88 \\
\hline Means & 3.12 & 3.17 & $3 \cdot 57$ & 3.86 & 3.43 \\
\hline Standard deviation & 0.92 & 0.94 & 0.81 & 0.62 & 0.69 \\
\hline Variance coefficient & 0.29 & 0.29 & 0.24 & 0.16 & 0.19 \\
\hline Skewness |Sk| & 0.28 & 0.38 & 0.32 & 0.73 & 0.34 \\
\hline Kurtosis |Ku| & 0.40 & 0.31 & 0.04 & 1.16 & 0.15 \\
\hline
\end{tabular}


To check the model's discriminant validity, we analyzed cross loads. Table 3 shows that indicators have higher loads for some constructs and lower loads for others, indicating discriminant validity, per Ringle et al. (2014) and Urbach and Ahlemann (2010).

Table 3. Cross loads to assess discriminant validity

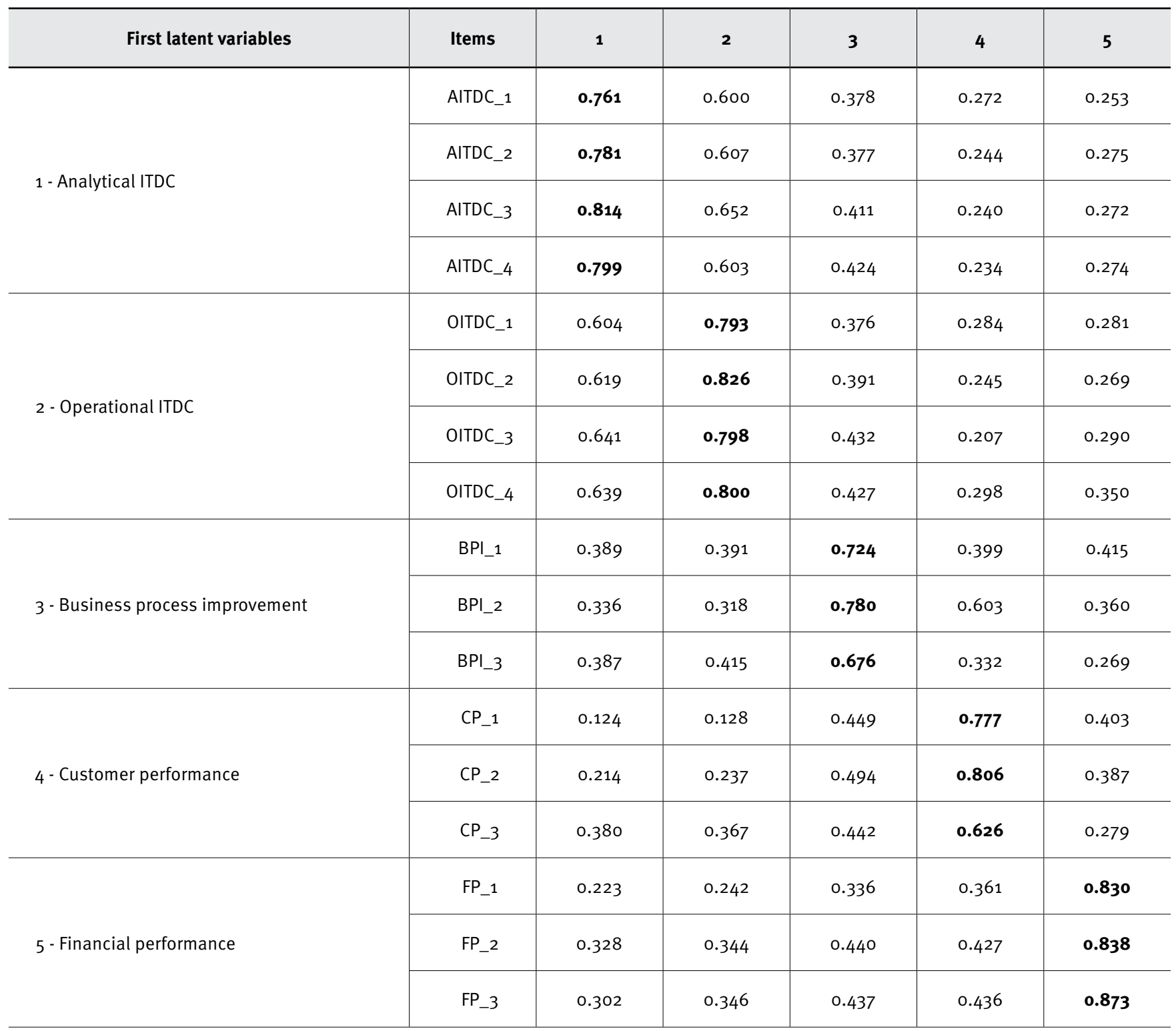

Table 3 shows results generated for cross loads. The indicators have significant loads ( $p$-value $<0.001$ ) in their constructs, confirming convergent validity. Discriminant validity is revealed when a load has the highest indicators in its latent variables. We estimated significance using the bootstrap method with 845 cases and 2,000 repetitions.

\section{Structural model}

To check for multicollinearity, we analyzed variance inflation factors (VIFs) for the FP and CP. The highest VIF is 1.897 for the "Operational ITDC" construct; there is no evidence of multicollinearity among the indicators per the limit recommended ( $<$ 5) by Marôco (2010).

We verified the effects of latent variables and control variables of sector and firm size (number of employees) on relationships between exogenous and endogenous variables (Table 4 ). 
Table 4. Effects of latent and control variables in relationships between exogenous and endogenous variables

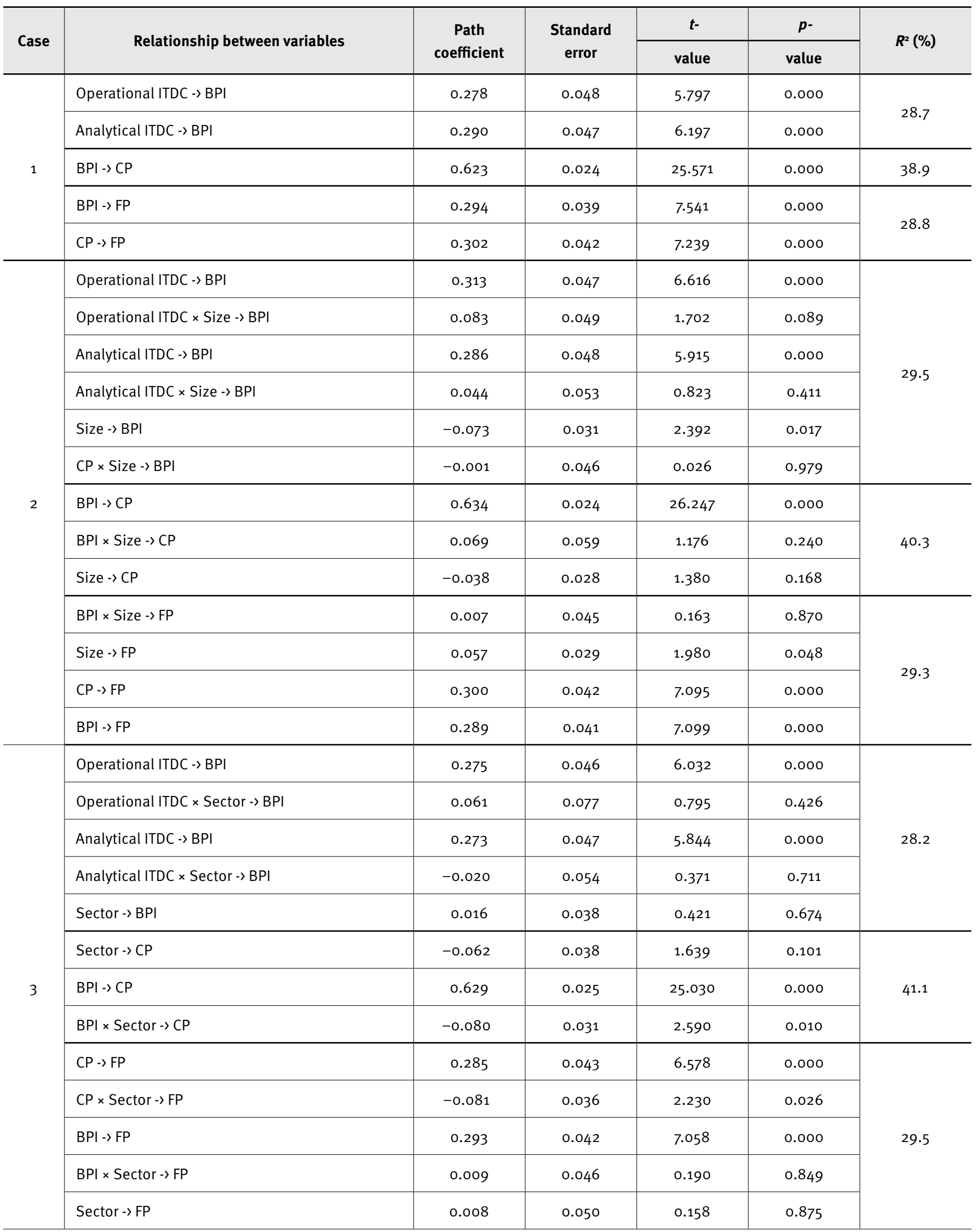


Case 1 shows that relationships between all latent variables are statistically significant ( $p$-value $<0.001$ ). Case 2 demonstrates that all effects of firm size moderation on the relationship between exogenous and endogenous variables are not statistically significant ( $p$-value $<0.05)$; firm size has a small direct influence on BPI (-0.073) and FP (0.057). Case 3 demonstrates that the effect of sector moderation on the relationship between ITDC (operational and analytical) and BPI is not statistically significant ( $p$-value $<0.05)$. Sector moderation has a small effect on relationships between $\mathrm{BPI}$ and $\mathrm{CP}$ and between $\mathrm{CP}$ and $\mathrm{FP}$, which were statistically significant ( $p$-value $<0.05)$.

We checked ITDC's direct effect on all endogenous variables, finding that the analytical ITDC influences FP ( $p$-value < 0.05 ; Table 5).

\section{Table 5 . Influence of IT-enabled dynamic capability on endogenous variables}

\begin{tabular}{|c|c|c|c|c|c|}
\hline Relationship between variables & Path coefficient & Standard error & $\begin{array}{c}t- \\
\text { value }\end{array}$ & $\begin{array}{c}p- \\
\text { Value }\end{array}$ & $R^{2}(\%)$ \\
\hline Operational ITDC -> BPI & 0.278 & 0.049 & 5.725 & 0.000 & \multirow{2}{*}{28.68} \\
\hline Analytical ITDC -> BPI & 0.290 & 0.048 & 6.054 & 0.000 & \\
\hline Operational ITDC -> CP & -0.016 & 0.045 & 0.355 & 0.723 & \multirow{3}{*}{38.87} \\
\hline Analytical ITDC $->C P$ & 0.021 & 0.048 & 0.442 & 0.659 & \\
\hline $\mathrm{BPI}->\mathrm{CP}$ & 0.621 & 0.031 & 20.033 & 0.000 & \\
\hline Analytical ITDC -> FP & 0.154 & 0.050 & 3.090 & 0.002 & \multirow{4}{*}{31.06} \\
\hline Operational ITDC -> FP & 0.022 & 0.050 & 0.444 & 0.657 & \\
\hline $\mathrm{BPI}->\mathrm{FP}$ & 0.207 & 0.044 & 4.654 & 0.000 & \\
\hline$C P->F P$ & 0.300 & 0.041 & 7.256 & 0.000 & \\
\hline
\end{tabular}

Coefficients of determination ( $R^{2}$ outcome) measure the variance of endogenous variables, indicating the structural model's quality. All coefficients of determination demonstrate large effects, as shown in Tables 4 and 5 . Cohen (1988) suggests the following classification for social and behavioral sciences: $R^{2}=2 \%$ is a small effect, $R^{2}=13 \%$ is a medium effect, and $R^{2}=26 \%$ is a large effect.

\section{Direct and indirect effects of IT-enabled dynamic capability and business process improvement}

We checked all mediation analyses to identify direct and indirect effects of ITDC and BPI. We estimated direct effects without the potential mediator variables BPI and CP. Table 6 shows the significance analysis of path coefficients without the mediator (Ringle et al., 2012), using the bootstrapping procedure (845 cases per subsample, 5,000 subsamples, and no sign changes). Both relationships are statistically significant ( $p$-value $<0.001$ ).
Table 6. Path coefficient results estimated without the potential mediator

\begin{tabular}{l|c|c|c}
\hline $\begin{array}{c}\text { Relationship between } \\
\text { variables }\end{array}$ & $\begin{array}{c}\text { Path } \\
\text { coefficient }\end{array}$ & $\begin{array}{c}\boldsymbol{t} \text { value } \\
\text { Operational ITDC -> CP }\end{array}$ & $\begin{array}{c}\boldsymbol{p} \text { - } \\
\text { value }\end{array}$ \\
\hline Operational ITDC -> FP & 0.381 & 14.082 & 0.000 \\
\hline Analytical ITDC -> CP & 0.343 & 11.082 & 0.000 \\
\hline Analytical ITDC -> FP & 0.378 & 13.410 & 0.000 \\
\hline BPI -> FP & 0.377 & 12.916 & 0.000 \\
\hline
\end{tabular}

We concluded that indirect effects should exist (Zhao, Lynch, \& Chen, 2010). We included the mediator variable in the PLS-PM and checked the VAF (Table 7). 
Table 7. Results of variance accounted for (VAF)

\begin{tabular}{|c|c|c|c|c|c|c|c|}
\hline Operational ITDC -> BPI -> FP & 0.057 & 0.027 & 0.822 & 0.411 & 0.022 & 0.079 & 72 \\
\hline Analytical ITDC -> BPI -> CP & 0.180 & 0.002 & $9 \cdot 577$ & 0.000 & 0.021 & 0.201 & 90 \\
\hline Analytical ITDC $->$ BPI -> FP & 0.060 & 0.023 & 6.789 & 0.000 & 0.154 & 0.214 & 28 \\
\hline Analytical ITDC $>$ CP $>$ FP & 0.063 & 0.019 & 8.171 & 0.000 & 0.154 & 0.217 & 29 \\
\hline
\end{tabular}

Due to significant indirect effects, we analyzed the VAF value as it determines the size of the ratio of indirect effect to total effect (Hair et al., 2013). Per the authors, when the VAF is less than $20 \%$, almost no mediation takes place, while a VAF exceeding $80 \%$ results in large outcomes, and we can assume full mediation. When the VAF lies between 20 and $80 \%$, we see partial mediation. Our results indicate full mediation by BPI in relationships between operational ITDC and CP, and between analytical ITDC and CP. No mediation by BPI and CP exists in the relationship between operational ITDC and FP. Partial mediation by $\mathrm{BPI}$ and FP exists in the relationship between analytical ITDC and FP. Partial mediation by CP exists in the relationship between $\mathrm{BPI}$ and FP. Only the mediation by BPI in the relationship between operational ITDC and FP was not significant ( $p$-value $<0.05$ ).

\section{Effect size $\left(f^{2}\right)$ and predictive relevance $\left(Q^{2}\right)$}

We evaluated the quality of model adjustment using two other indicators' values: effect size $\left(f^{2}\right)$ or Cohen's indicator, and relevance or predictive validity $\left(Q^{2}\right)$ or Stone-Geisser indicator.

$f^{2}$ was obtained by including and excluding model constructs one by one. We evaluated the usefulness of each construct for the adjustment model. We considered values of $0.02,0.15$, and 0.35 small, medium, and large, respectively (Hair et al., 2013). We evaluated $f^{2}$ in terms of the ratio between the parts explained and not explained $\left(f^{2}=R^{2} /\left(1-R^{2}\right)\right.$. Table 8 shows the values of $f^{2}$ and BPI when the excluded constructs had large effects on CP.

Table 8. Results of effect size $\left(f^{2}\right.$

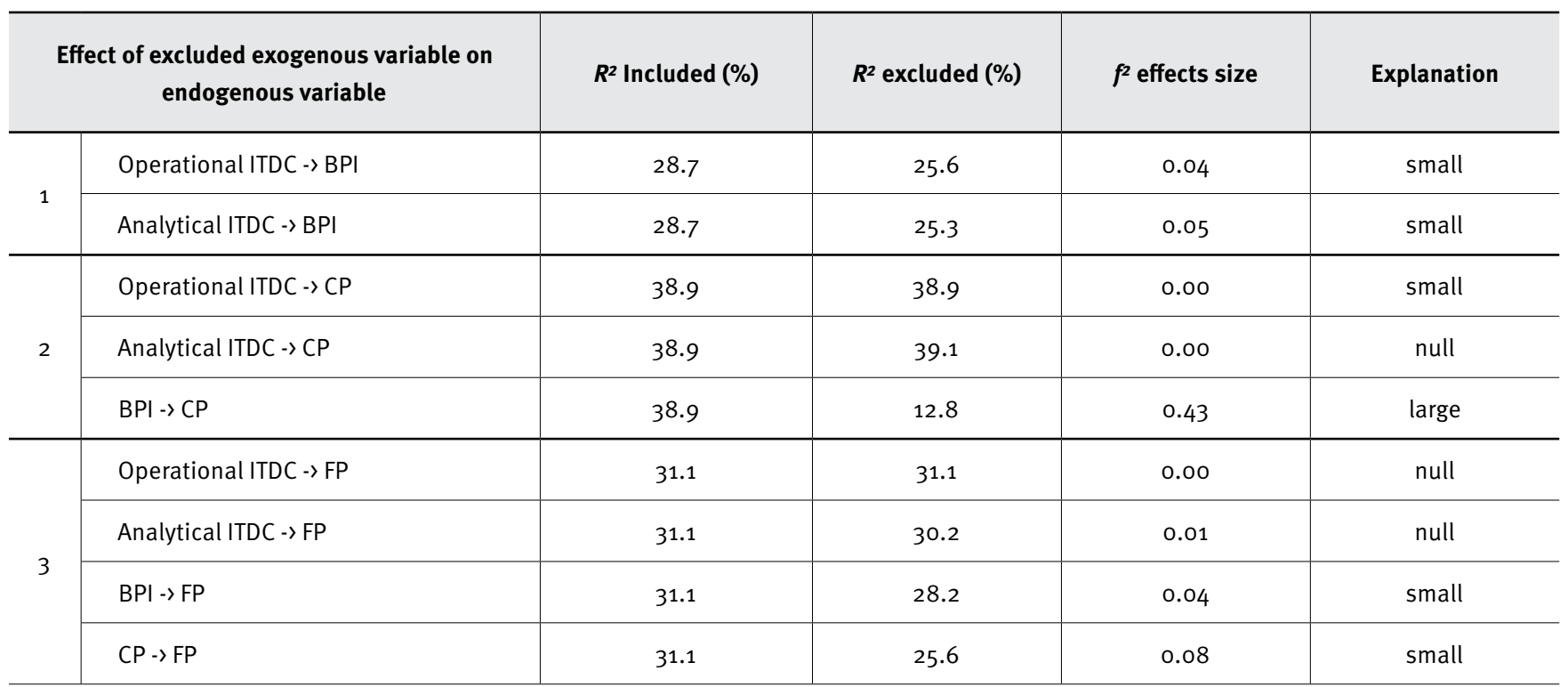


$Q^{2}$ evaluates the model's validity or how well the model measures what it was designed to measure (model prediction quality or accuracy of adjusted model) (Chin, 1998). The values should be greater than zero (Ringle et al., 2014). All $Q^{2}$ values are higher than zero (Table 9), supporting the model's predictive relevance regarding endogenous latent variables. We calculated the predictive relevance of exogenous variables on endogenous variables. In Cases 1 and 3, all exogenous variables show small or null predictive relevance for endogenous variables. The $Q^{2}$ for CP (Case 2) shows that BPI has medium predictive relevance (Table 9).

Table 9. Results of predictive relevance $\left(Q^{2}\right)$ and effect size $\left(q^{2}\right)$

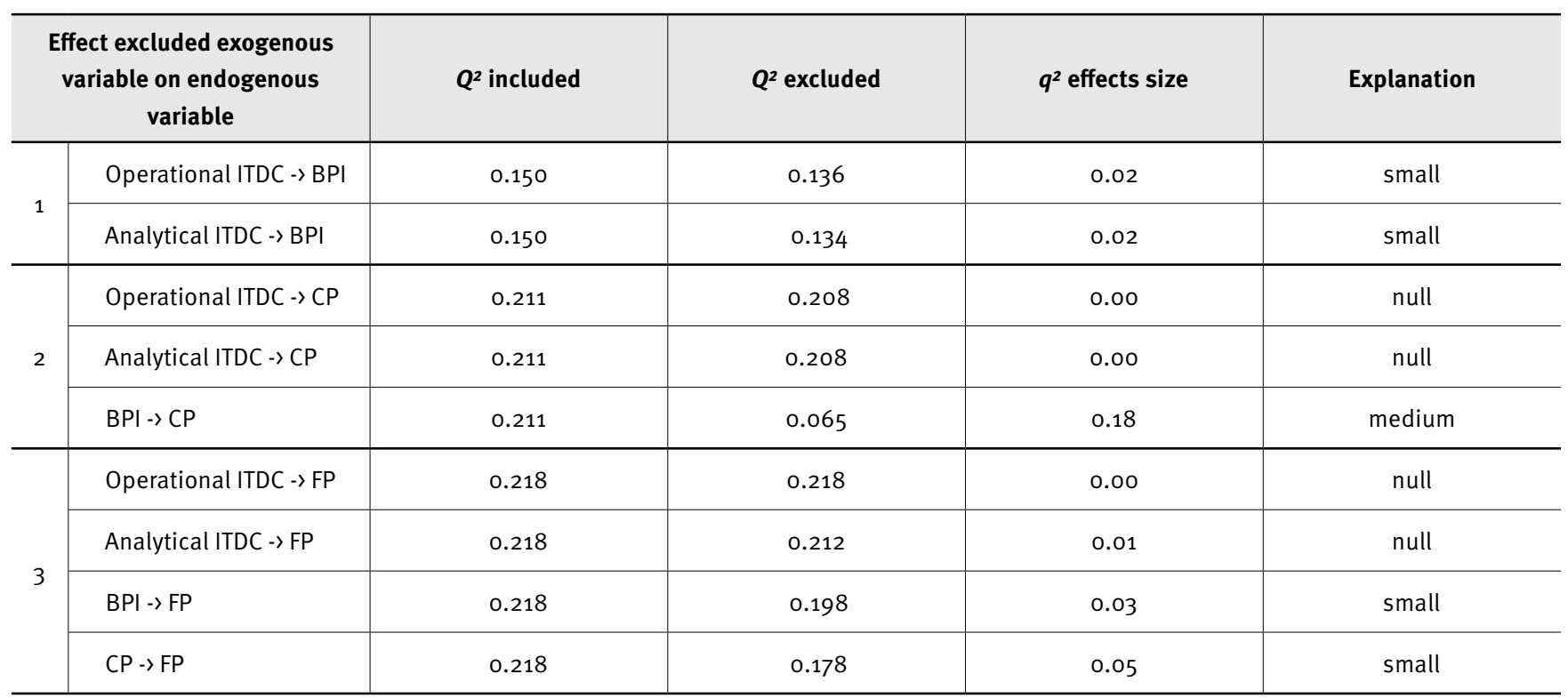

\section{Analyzing heterogeneous data structures by moderating control variables}

We checked differences between sector moderation, split the heterogeneous dataset, and compared sector groups to understand and further differentiate findings (Table 10).

Table 10. Effect of sector groups

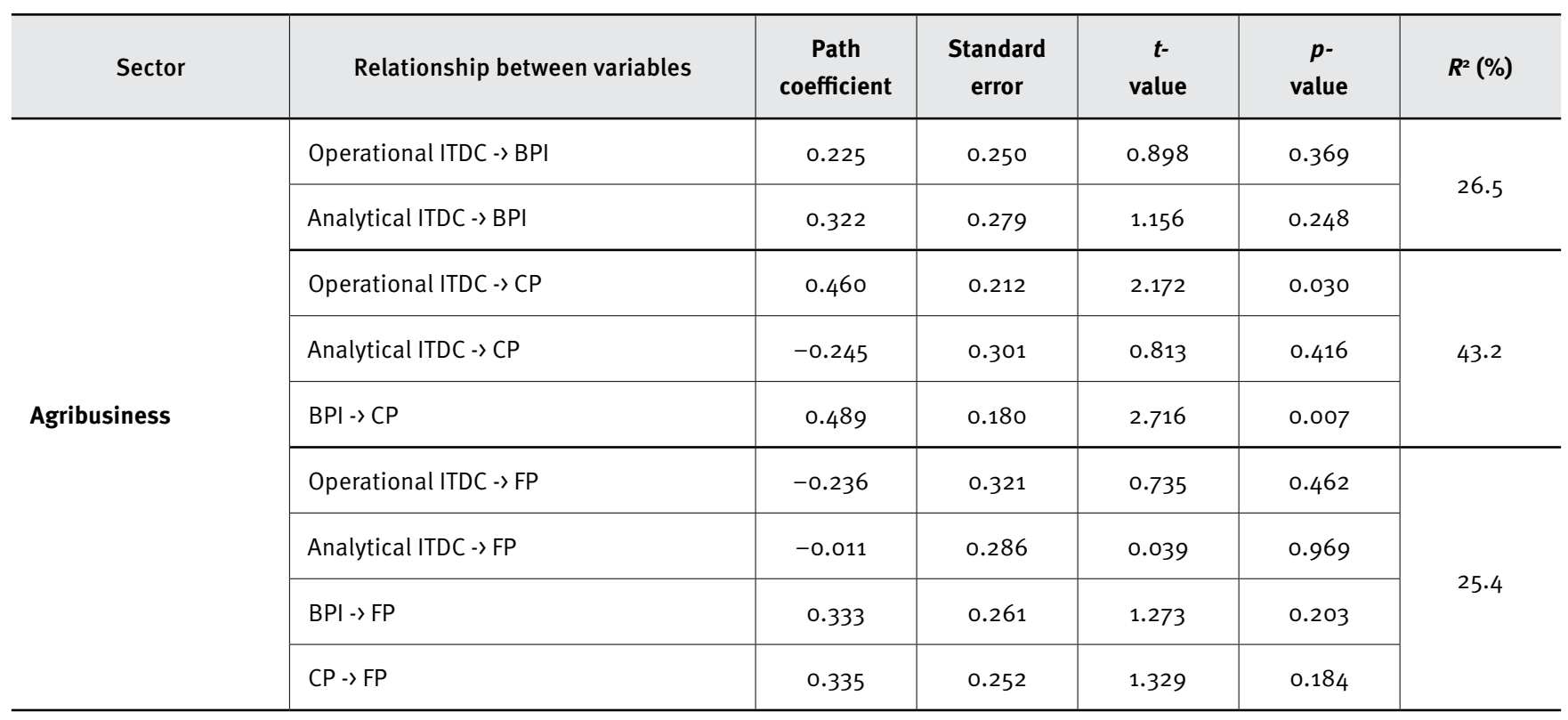




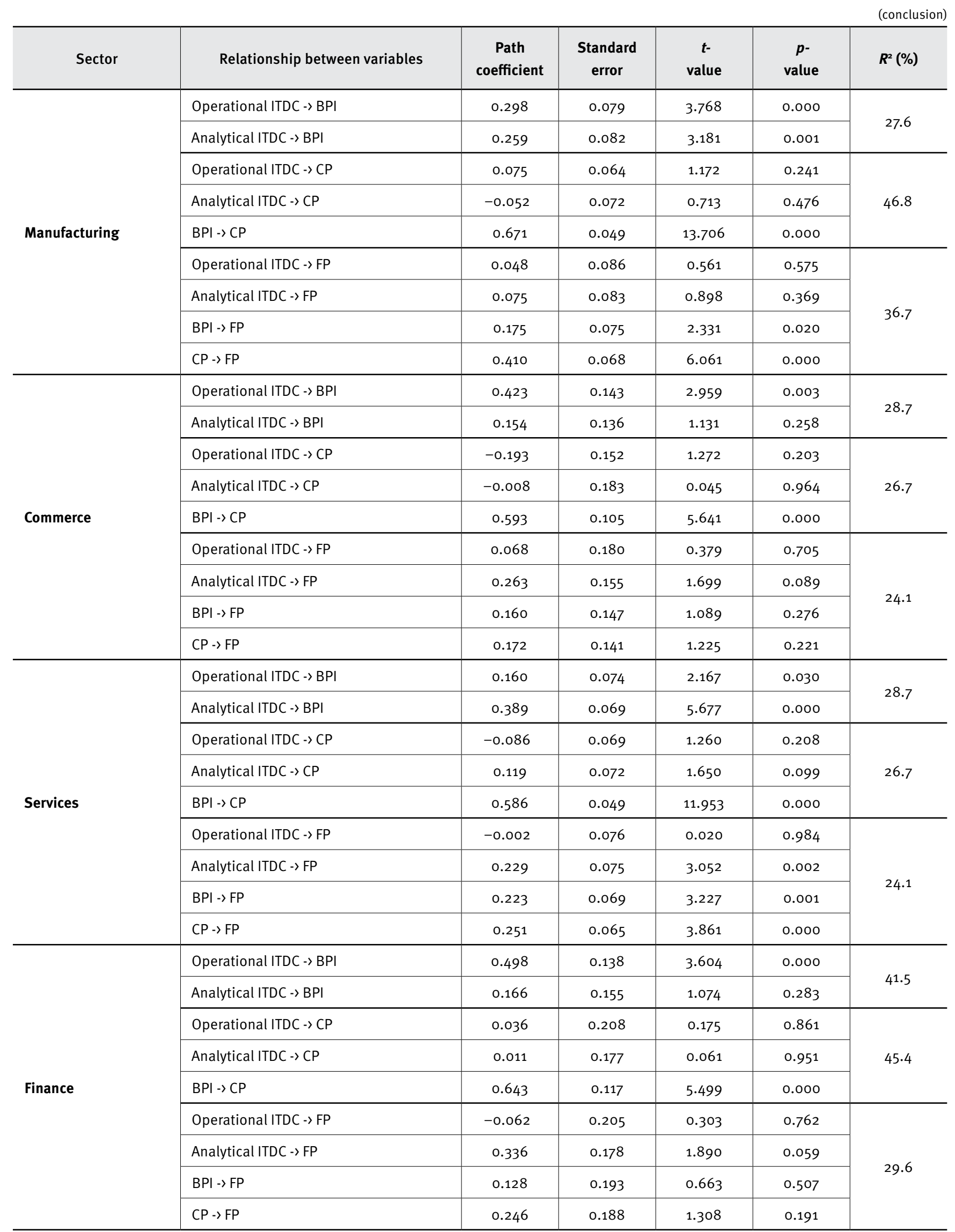


Agribusiness data show significant effects only for relationships between operational ITDC and $C P$, and between $\mathrm{BPI}$ and CP ( $p$-value $<0.05)$. The manufacturing data exert no significant effects for relationships between operational ITDC and CP, and between analytical ITDC and CP ( $p$-value $<0.05)$. The commerce data show no significant effects for relationships between operational ITDC and BPI, and between BPI and CPE ( $p$-value $<0.010)$. The services data indicate no significant effects for relationships between operational ITDC and BPI, between analytical ITDC and BPI, and between operational ITDC and FP ( $p$-value $<0.05)$. The finance data exert significant effects only for relationships between operational ITDC and BPI, and between BPI and CP ( $p$-value $<0.05)$.

We compared all data groups to verify differences in path coefficients by PLS multigroup analysis (PLS-MGA) (Hair et al., 2013). We did not find statistically significant ( $p$-value $<0.05$ ) differences in the path coefficients between the datasets of finance and manufacturing, finance and commerce, and finance and agribusiness. Significant ( $p$-value $<0.10$ ) differences exist in path coefficients between the datasets of manufacturing and services, manufacturing and agribusiness, manufacturing and commerce, services and agribusiness, services and commerce, and services and finance. We verified significant ( $p$-value $<0.05$ ) differences in path coefficients between the datasets of commerce and agribusiness.

\section{DISCUSSION AND CONCLUSION}

This study provides empirical evidence regarding the effect of ITDC on corporate performance in economic turbulence. The results of a conceptual BSC model (Kaplan, 2010) evidence linkages between ITDC, BPI, CP, and FP in economic turbulence.

Large firm size decreases BPI and small companies perform better at innovation, operation, and post-sales activities. Large firm size increases FP, and these companies earn better revenue by creating customer satisfaction, loyalty, and retention. The results of our control variables (sector and firm size) testing show that sector moderates the relationships between BPI and CP, and between CP and FP.

We conduct a detailed analysis of heterogeneous data by comparing data groups' results and find interesting difference effects in relationships between operational ITDC and CP. ITDC has strong effects on understanding customer needs, making timely delivery (products and services), and retaining clients. Comparing representative datasets for manufacturing (339 cases) and services (317 cases) shows a strong difference effect (0.160) between CP and FP (i.e., the manufacturing sector has a higher path coefficient than the services sector).
Hypotheses $\mathrm{H}_{1}$ (operational ITDC $>>\mathrm{BPI}$ ) and $\mathrm{H}_{2}$ (analytical ITDC $->\mathrm{BPI}$ ) show strong significance effects ( $p$-value $<0.05)$ of path coefficients, confirming that IT creates many operational and analytical benefits (Melville et al., 2004; Tallon, 2008), enabling DC to build and reconfigure internal competencies in value chain activities and achieve corporate performance. Operational and analytical ITDC have the same effect on BPI for innovation, operations, and post-sales (i.e., there are no differences in path coefficients).

We examine the process in which ITDC positively affects $\mathrm{CP}$ through increased proficiency by changing BPI. Relationships between operational and analytical ITDC and CP are fully mediated by BPI, consistent with other studies (Kaplan, 2010; Kaplan \& Norton, 2008; Melville et al., 2004; Tallon, 2008). The results highlight dynamic process management capabilities' importance in enhancing firm-level performance (Kim et al., 2011).

We examine the possible direct relationship between operational and analytical ITDC and FP. Operational ITDC $>$ FP shows no statistically significant effects. Analytical ITDC -> FP demonstrates significant effects. We identify partial mediation by BPI and CP for analytical ITDC $\left(Q^{2}>0\right)$. We check the direct effects in these relationships without the mediator, and all results are statistically significant ( $p$-value $<0.05)$. Although significant causality between the variables of ITDC and FP might exist, achieving consistent empirical findings is difficult when modeling based on the black box approach (Kim et al., 2011). Some studies using the black box approach cannot explain how IT investment and organizational performance are associated (Brynjolfsson, 1993; Brynjolfsson \& Hitt, 1996).

Hypotheses $\mathrm{H}_{3}$ (BPI -> CP) and $\mathrm{H}_{4}$ (BPI -> FP) confirm the causal relationship conceptualized in the BSC framework (Kaplan, 2010). BPI has a stronger effect (0.623) on CP than on FP (0.294). We conclude that innovation, operations, and postsales value chain activities focus more on generating value to satisfy customers than on reducing spending. We moderate BPI to confirm that IT enables DC to create benefits and improve business process performance (Schwarz et al., 2010). This is accomplished by understanding, analyzing, manufacturing, delivering (products and services), and improving client relationships, resulting in sustainable competitive advantage (Kaplan \& Norton, 2008; Ramdani, 2012) in the uncertain Brazilian environment.

Hypothesis $\mathrm{H}_{5}$ ( $\mathrm{CP}$-> FP) confirms the causal relationship of the BSC framework (Kaplan \& Norton, 1996). The empirical study confirms that delivery of market attributes promotes customer satisfaction, leading to client retention and added value to customers. It finds higher variation in $\mathrm{FP}\left(R^{2}=28.8 \%\right)$ and that the effects of CP and BPI on FP (0.302 and 0.294 , respectively) are not different $(p$-value $<0.05)$. 
We identify operational and analytical ITDC's benefits for corporate performance using survey-based research supported by empirical evidence. Our sample comprises Brazilian firms under economic turbulence (GDP $=-3.8 \%$ ); most previous studies use data from stable economies in North America and Europe. Few studies pertaining to Brazil explicitly model and empirically test the effects of ITDC on corporate performance using the BSC model in economic crisis.

\section{LIMITATIONS AND FUTURE OPPORTUNITIES}

This study's weakness is its latent variables, which require assumptions regarding measurement and may not reflect the realities of executive ITDC perceptions, business process improvement, customer performance, or financial performance.

Future research opportunities include qualitative research, specifically how and why control variables such as sector, firm size, and environmental challenge influence the ITDC regarding corporate performance. The study could be repeated using the following constructs: (1) impacts of IT resource adoption on corporate performance and (2) other effects of ITDC use on corporate performance. Researchers may compare structural effects to identify different influences and uses of IT adoption.

\section{AUTHORS' NOTE}

The PLS-MGA data group comparisons' questionnaire, tables of cross-group data by sector, and results are available from the first author.

\section{REFERENCES}

Albertin, A. L., \& Albertin, R. M. M. (2016). Information technology and corporate performance: The IT use dimension and benefits to business (3rd ed.). São Paulo, Brazil: Atlas.

Ambrosini, V., \& Bowman, C. (2009). What are dynamic capabilities and are they a useful construct in strategic management? International Journal of Management Reviews, 11(1), 29-49. doi:10.1111/j.14682370.2008.00251.x

Anderson, M. C., Banker, R. D., \& Ravindran, S. (2006). Value implications of investments in information technology. Management Science, 52(9), 1359-1376. doi:10.1287/mnsc.1060.0542

Arnott, D., \& Pervan, G. (2005). A critical analysis of decision support systems research. Journal of Information Technology, 20(2), 67-87. doi:10.1057/palgrave.jit.2000035
Arnott, D., \& Pervan, G. (2014). A critical analysis of decision support systems research revisited: The rise of design science. Journal of Information Technology, 29(4), 269-293. doi:10.1057/jit.2014.16

Atkinson, A. A., Kaplan, R. S., Matsumura, E. M., \& Young, S. M. (2011). Management accounting: Information for decision-making and strategy execution (6th ed.). Englewood Cliffs, USA: Prentice Hall.

Augier, M., \& Teece, D. J. (2009). Dynamic capabilities and the role of managers in business strategy and economic performance. Organization Science, 20(2), 410-421. doi:10.1287/orsc.1090.0424

Barney, J. (1991). Firm resources and sustained competitive advantage. Journal of Management, 17(1), 99-120. doi:10.1177/014920639101700108

Barney, J. B., \& Clark, D. N. (2007). Resource-based theory: Creating and sustaining competitive advantage. New York, USA: Oxford University Press.

Bento, A., Bento, R., \& White, L. F. (2013). Validating cause-and-effect relationships in the balanced scorecard. Academy of Accounting and Financial Studies Journal, 17(3), 45-55.

Bharadwaj, A. S. (2000). A resource-based perspective on information technology capability and firm performance: An empirical investigation. MIS Quarterly, 24(1), 169-196. doi:10.2307/3250983

Bhatt, G. D., \& Grover, V. (2005). Types of information technology capabilities and their role in competitive advantage: An empirical study. Journal of Management Information Systems, 22 (2), 253-277.

Birkinshaw, J., \& Goddard, J. (2009). What is your management model? MIT Sloan Management Review, 50(2). Retrieved from http:// sloanreview.mit.edu/

Brito, R. P. de., \& Brito, L. A. L. (2012). Vantagem competitiva, criação de valor e seus efeitos sobre o desempenho. RAE-Revista de Administração de Empresas, 52(1), 70-84. doi:0.1590/So03475902012000100006

Bryant, L., Jones, D. A., \& Widener, S. K. (2004). Managing value creation within the firm: An examination of multiple performance measures. Journal of Management Accounting Research, 16(1), 107131. doi:10.2308/jmar.2004.16.1.107

Brynjolfsson, E. (1993). The productivity paradox of information technology. Communications of the ACM, 36(12), 66-77.

Brynjolfsson, E., \& Hitt, L. (1996). Paradox lost? Firm-level evidence on the returns to information systems spending. Management Science, 42(4), 541-558. doi:10.1287/mnsc.42.4.541

Chin, W. W. (1998). The partial least squares approach for structural equation modeling. In G. A. Marcoulides (Ed.), Modern methods for business research (pp. 295-336). London, UK: Lawrence Erlbaum Associates.

Chuang, S. (2004). A resource-based perspective on knowledge management capability and competitive advantage: An empirical investigation. Expert Systems with Applications, 27(3), 459-465. doi:10.1016/j.eswa.2004.05.008

Cohen, J. (1988). Statistical power analysis for the behavioral sciences (2nd ed.). New York, USA: Psychology Press.

D'Arcy, J., \& Devaraj, S. (2012). Employee misuse of information technology resources: Testing a contemporary deterrence model. Decision Sciences, 43(6), 1091-1124. doi:10.1111/j.15405915.2012.00383.x

Davenport, T. H., \& Harris, J. G. (2007). Competing on analytics: The new science of winning. Cambridge, USA: Harvard Business Press. 
Davenport, T. H., Harris, J. G., \& Morison, R. (2010). Analytics at work: Smarter decisions, better results. Cambridge, USA: Harvard Business Press.

Davern, M. J., \& Wilkin, C. L. (2010). Towards an integrated view of IT value measurement. International Journal of Accounting Information Systems, 11(1), 42-60. doi:10.1016/j.accinf.2009.12.005

Devaraj, S., \& Kohli, R. (2000). Information technology payoff in the healthcare industry: A longitudinal study. Journal of Management Information Systems, 16(4), 41-67.

Devaraj, S., \& Kohli, R. (2003). Performance impacts of information technology: Is actual usage the missing link? Management Science, 49(3), 273-289.

Eisenhardt, K. M., \& Martin, J. A. (2000). Dynamic capabilities: What are they? Strategic Management Journal, 21(10-11), 1105-1121. doi:10.1002/10970266(200010/11)21:10/11/1105::aid-smj133’3.0.c0;2-e

Faul, F., Erdfelder, E., Lang, A. G., \& Buchner, A. (2007). G*Power 3: A flexible statistical power analysis program for the social, behavioral, and biomedical sciences. Behavior Research Methods, 39(2), 175-191. doi:10.3758/BF03193146

Grant, R. M. (2010). Contemporary strategy analysis and cases: Text and cases. New York, USA: John Wiley \& Sons.

GVCia. (2015). Annual research on management and IT use in business (26th ed.). Sao Paulo, Brazil: FGV-EAESP-CIA.

Hair, J. F., Black, W. C., Babin, B. J., Anderson, R. E., \& Tatham, R. L. (2009). Análise multivariada de dados. São Paulo, Brasil: Bookman Editora.

Hair, J. F., Jr., Hult, G., Ringle, C., \& Sarstedt, M. (2013). A primer on partial least squares structural equation modeling (PLS-SEM). Thousand Oaks, USA: Sage.

Helfat, C. E., Finkelstein, S., Mitchell, W., Peteraf, M., Singh, H., Teece, D., \& Winter, S. G. (2009). Dynamic capabilities: Understanding strategic change in organizations. John Wiley \& Sons.

Helfat, C. E., \& Peteraf, M. A. (2009). Understanding dynamic capabilities: Progress along a developmental path. Strategic organization, 7(1), 91-102. doi:10.1177/1476127008100133

Helfat, C. E., \& Winter, S. G. (2011). Untangling dynamic and operational capabilities: Strategy for the (n)ever-changing world. Strategic Management Journal, 32(11), 1243-1250. doi:10.1002/smj.955

Henderson, B., Kobelsky, K. W., Richardson, V. J., \& Smith, R. (2010). The relevance of information technology expenditures. Journal of Information Systems, 24(2), 39-77. doi:10.2308/jis.2010.24.2.39

Henderson, J., \& Venkatraman, N. (1999). Strategic alignment: Leveraging information technology for transforming organizations. IBM Systems Journal, 32(1), 472-484. doi:10.1147/sj.382.0472

Henseler, J., Ringle, C. M., \& Sinkovics, R. R. (2009). The use of partial least squares path modeling in international marketing. Advances in International Marketing, 20, 277-319.

Instituto Brasileiro de Geografia e Estatística. (2016). Study of gross domestic product of 2015. Retrieved from http://www.ibge.gov.br/ home/estatistica/indicadores/pib/defaultcnt.shtm

Jordão, R. V. D., \& Novas, J. L. C. (2013). A study on the use of the balanced scorecard for strategy implementation in a large Brazilian mixed economy company. Journal of Technology Management \& Innovation, 8(3), 98-107.
Kaplan, R. (2010). Conceptual foundations of the balanced scorecard [Working Paper $\mathrm{N}^{\circ}$ 10-074]. Harvard Business School Accounting \& Management Unit, Boston, USA.

Kaplan, R., \& Norton, D. P. (1992). The balanced scorecard: Measures that drive performance. Harvard Business Review, 70(1). Retrieved from https://hbr.org/

Kaplan, R., \& Norton, D. P. (1996). The balanced scorecard: Translating strategy into action. Boston, USA: Harvard Business Press.

Kaplan, R., \& Norton, D. P. (2000). The strategy-focused organization: How balanced scorecard companies thrive in the new business environment. Boston, USA: Harvard Business Review Press.

Kaplan, R., \& Norton, D. P. (2004). The strategy map: Guide to aligning intangible assets. Strategy \& Leadership, 32(5), 10-17. doi:10.1108/10878570410699825

Kaplan, R., \& Norton, D. P. (2008). The execution premium: Linking strategy to operations for competitive advantage. Boston, USA: Harvard Business Review Press.

Kim, G., Shin, B., Kim, K. K., \& Lee, H. G. (2011). IT capabilities, processoriented dynamic capabilities, and firm financial performance. Journal of the Association for Information Systems, 12 (7), 487-517.

Kohli, R., Devaraj, S., \& Ow, T. T. (2012). Does information technology investment influence a firm's market value? A case of non-publicly traded healthcare firms. MIS Quarterly, 36(4), 1145-1163.

Kohli, R., \& Grover, V. (2008). Business value of IT: An essay on expanding research directions to keep up with the times. Journal of the Association for Information Systems, 9(1), 23-39.

Maçada, A. C. G., Beltrame, M. M., Dolci, P. C., \& Becker, J. L. (2012). IT business value model for information intensive organizations. BARBrazilian Administration Review, 9(1), 44-65. doi:10.1590/S180776922012000100004

Malhotra, N. K. (2006). Pesquisa de marketing: Uma orientação aplicada (4th ed.). Porto Alegre, RS: Bookman.

Marôco, J. (2010). Análise de equações estruturais: Fundamentos teóricos. Software e aplicações. Sao Paulo, SP: Pêro Pinheiro.

McKelvie, A., \& Davidsson, P. (2009). From resource base to dynamic capabilities: An investigation of new firms. British Journal of Management, 20(1), S63-S80. doi:10.1111/j.1467-8551.2008.00613.x

Meirelles, S. D., \& Camargo, Á. A. B. (2014). Capacidades dinâmicas: O que são e como identificá-las? RAC-Revista de Administração Contemporânea, 18(7), 41-64. doi:10.1590/1982-7849rac20141289

Melville, N., Kraemer, K., \& Gurbaxani, V. (2004). Information technology and organizational performance: An integrative model of IT business value. MIS Quarterly, 28(2), 283-322.

Najmi, M., Etebari, M., \& Emami, S. (2012). A framework to review performance prism. InternationalJournalofOperations and Production Management, 32(10), 1124-1146. doi:10.1108/01443571211274486

Nitzl, C., \& Hirsch, B. (2013). When do managers trust their management accountants? [SSRN Working Paper, pp. 1-46]. Bundeswehr University, Munich, Germany.

Nudurupati, S. S., Bititci, U. S., Kumar, V., \& Chan, F. T. (2011). State of the art literature review on performance measurement. Computers \& Industrial Engineering, 60(2), 279-290. doi:10.1016/j. cie.2010.11.010

O’Brien, J. A., \& Marakas, G. M. (2007). Management information systems (10th ed.). New York, USA, McGraw-Hill/Irwin, a business unit of The McGrawHill Companies. 
Otim, S., Dow, K., Grover, V., \& Wong, J. (2012). The impact of information technology investments on downside risk of the firm: Alternative measurement of the business value of IT. Journal of Management Information Systems, 29(1), 159-194. doi:10.2753/MISo742-1222290105

Ouakouak, M. L., \& Ouedraogo, N. (2013). The mediating role of employee strategic alignment in the relationship between rational strategic planning and firm performance: A European study. Canadian Journal of Administrative Sciences, 30(3), 143-158. doi:10.1002/cjas.1259

Papke-Shields, K. E., Malhotra, M. K., \& Grover, V. (2006). Evolution in the strategic manufacturing planning process of organizations. Journal of Operations Management, 24(5), 421-439. doi:10.1016/j. jom.2005.11.012

Pavlou, P. A., \& Sawy, O. A. El. (2011). Understanding the elusive black box of dynamic capabilities. Decision Sciences, 42(1), 239-273. doi:10.1111/j.1540-5915.2010.00287.x

Poelmans, S., Reijers, H. A., \& Recker, J. (2013). Investigating the success of operational business process management systems. Information Technology and Management, 14(4), 295-314. doi:10.1007/s10799013-0167-8

Powell, T. C., \& Dent-Micallef, A. (1997). Information technology as competitive advantage: The role of human, business, and technology resources. Strategic Management Journal, 18(5), 375-405. doi:10.1002/ (sici)1097-0266(199705)18:5‘375::aid-smj876`3.0.c0;2-7

Ramakrishnan, T., Jones, M. C., \& Sidorova, A. (2012). Factors influencing business intelligence (BI) data collection strategies: An empirical investigation. Decision Support Systems, 52(2), 486-496. doi:10.1016/j.dss.2011.10.009

Ramdani, B. (2012). Information technology and organisational performance: Reviewing the business value of IT literature. In Y. K. Dwivedi, M. R. Wade, \& S. L. Schneberger (Eds.), Information systems theory: Explaining and predicting our digital society (Vol. 1, pp. 283 301). New York, USA: Springer.

Raschke, R. L. (2010). Process-based view of agility: The value contribution of IT and the effects on process outcomes. International Journal of Accounting Information Systems, 11(4), 297-313. 10.1016/j. accinf.2010.09.005

Ravichandran, T., \& Lertwongsatien, C. (2005). Effect of information systems resources and capabilities on firm performance: A resource-based perspective. Journal of Management Information Systems, 21(4), 237-276.

Ray, G., Wu, D., \& Konana, P. (2009). Competitive environment and the relationship between IT and vertical integration. Information Systems Research, 20(4), 585-603. doi:10.1287/isre.1080.0202

Ringle, C., Sarstedt, M., \& Straub, D. (2012). A critical look at the use of PLS-SEM in MIS Quarterly. MIS Quarterly, 36(1), 3-14

Ringle, C., Silva, D., \& Bido, D. S. (2014). Modelagem de equações estruturais com utilização do Smartpls. Revista Brasileira de Marketing, 13(2), 54-71. doi:10.5585/remark.v13i2.2717

Ringle, C., Wende, S., \& Will, A. (2005). SmartPLS 2.0 M3. Retrieved from http://www.smartpls.de

Santos, B. L. dos, Zheng, Z., Mookerjee, V. S., \& Chen, H. (2012). Are new IT-enabled investment opportunities diminishing for firms? Information Systems Research, 23(2), 287-305.

Santos-Vijande, M. L., López-Sánchez, J. Á., \& Trespalacios, J. A. (2012). How organizational learning affects a firm's flexibility, competitive strategy, and performance. Journal of Business Research, 65(8), 1079-1089. doi:10.1016/j.jbusres.2011.09.002
Schwarz, A., Kalika, M., Kefi, H., \& Schwarz, C. (2010). A dynamic capabilities approach to understanding the impact of IT-enabled business processes and IT-business alignment on the strategic and operational performance of the firm. Communications of the Association for Information Systems, 26(1), 57-84.

Sekaran, U. (2000). Research methods for business: A skill-building approach (3rd ed.). New York, USA: John Wiley.

Sen, D., Bingol, S., \& Vayvay, O. (2017). Strategic enterprise management for innovative companies: The last decade of the balanced scorecard. International Journal of Asian Social Science, 7(1), 97-109. doi:10.18488/journal.1/2017.7.1/1.1.97.109

Shang, S., \& Seddon, P. B. (2002). Assessing and managing the benefits of enterprise systems: The business manager's perspective. Information Systems Journal, 12(4), 271-299. doi:10.1046/j.13652575.2002.00132.x

Sila, I., \& Ebrahimpour, M. (2005). Critical linkages among TQM factors and business results. International Journal ofOperations \& Production Management, 25(11), 1123-1155. doi:10.1108/01443570510626925

Singh, S., Watson, H. J., \& Watson, R. (2002). EIS support for the strategic management process. Decision Support Systems, 33(1), 7185. doi:10.1016/S0167-9236(01)00129-4

Sobol, M. G., \& Klein, G. (2009). Relation of ClO background, IT infrastructure, and economic performance. Information \& Management, 46(5), 271-278. doi:10.1016/j.im.2009.05.001

Sosik, J. J., Kahai, S., \& Piovoso, M. J. (2009). Silver bullet or voodoo statistics? A primer for using the partial least squares data analytic technique in group and organization research. Group \& Organization Management, 34(1), 5-36. doi:10.1177/1059601108329198

Stoel, M. D., \& Muhanna, W. A. (2009). IT capabilities and firm performance: A contingency analysis of the role of industry and IT capability type. Information and Management, 46(3), 181-189. doi:10.1016/j.im.2008.10.002

Tallon, P. P. (2008). A process-oriented perspective on the alignment of information technology and business strategy. Journal of Management Information Systems, 24(3), 227-268. doi:10.2753/ MISO742-1222240308

Tallon, P. P., Kraemer, K. L., \& Gurbaxani, V. (2000). Executives' perceptions of the business value of information technology: A process-oriented approach. Journal of Management Information Systems, 16(4), 145-173. doi:10.1080/07421222.2000.11518269

Teece, D. J. (2009). Dynamic capabilities and strategic management: Organizing for innovation and growth. New York, USA: Oxford University Press.

Teece, D. J. (2014). A dynamic capabilities-based entrepreneurial theory of the multinational enterprise. Journal of International Business Studies, 45(1), 8-37. doi:10.1057/jibs.2013.54

Teece, D. J., Pisano, G., \& Shuen, A. (1997). Dynamic capabilities and strategic management. Strategic Management Journal, 18(7), 509-533. doi:10.1002/(sici)1097-0266(199708)18:7〈509::aid-smj882’3.0.c0;2-z

Urbach, N., \& Ahlemann, F. (2010). Structural equation modeling in information systems research using partial least squares. Journal of Information Technology Theory and Application, 11(2), 5-39.

Wade, M., \& Hulland, J. (2004). The resource-based view and information systems research: Review, extension, and suggestions for future research. MIS Quarterly, 28(1), 107-142. 
Wang, C. L., \& Ahmed, P. K. (2007). Dynamic capabilities: A review and research agenda. International Journal of Management Reviews, 9(1), 31-51. doi:10.1111/j.1468-2370.2007.00201.x

Weill, P., Subramani, M., \& Broadbent, M. (2002). Building IT infrastructure for strategic agility. MIT Sloan Management Review, 44(1). Retrieved from http://sloanreview.mit.edu/

Winter, S. G. (2003). Understanding dynamic capabilities. Strategic Management Journal, 24(10), 991-995. doi:10.1002/smj.318

Yoshikuni, A. C., \& Albertin, A. L. (2014). Model analysis of the relationship between strategic organization knowledge and the use of information systems in firm performance in Brazil. Chinese Business Review, 13(5), 301-319.
Zahra, S. A., Sapienza, H. J., \& Davidsson, P. (2006). Entrepreneurship and dynamic capabilities: A review, model and research agenda. Journal of Management Studies, 43(4), 917-955. doi:10.1111/j.1467 6486.2006.00616.x

Zhao, X., Lynch, J. G., \& Chen, Q. (2010). Reconsidering Baron and Kenny: Myths and truths about mediation analysis. Journal of Consumer Research, 37(2), 197-206. doi:10.1086/651257

Zollo, M., \& Winter, S. G. (2002). Deliberate learning and the evolution of dynamic capabilities. Organization Science, 13(3), 339-351. doi:10.1287/orsc.13.3.339.2780 